УДК 611.329013

DOI: $10.24061 / 1727-0847.17 .2 .2018 .11$

D.V. Proniaiev, I.G. Biryuk*, N.Ya. Kozariichuk**, A.A. Halahdina***, V.A. Goncharenko ${ }^{* * * *}$ Department of anaromy, topographical anatomy and operative surgery (head-prof. O.M. Slobodian), *Department of Disasters Medicine and Military Medicine (head - doc. I.G. Biryuk), **B.L. Radzikhovckyi Department of Ophthalmology (head-prof. Ya.I. Penishkevych), ***Department of Surgical Stomatology and Maxillofacial Surgery (head-N.B. Kuzniak), ****Department of pediatric dentistry (head-O.I. Hodovanets) of Higher State Educational Establishment of Ukraine "Bukovinian State Medical University"

\title{
FETAL ANATOMY OF THE ILEOCECAL SEGMENT
}

\section{ФЕТАЛЬНА АНАТОМІЯ КЛУБОВО-СЛІПОКИШКОВОГО СЕГМЕНТА}

Резюме. Дослідженню анатомії клубово-сліпокишкового сегмента присвячена велика кількість публікацій на сторінках сучасних вітчизняних та зарубіжних наукових виданьях. Дані більшості авторів фрагментарні, та неповні і здебільшого присвячені або дослідженню анатомії дефінітивної форми клубово-сліпокишкового сегмента, або ембріонального формоутворення клубового сосочка. В літературі відсутня спільна думка стосовно динаміки становлення клубового сосочка, варіантів його анатомії, механізму його замикальної функції. Дослідження проведено на 125 трупах та органокомплексах плодів і новонароджених людини без явних макроскопічних ознак відхилень від нормальної будови шлунково-кишкового тракту. Морфогенез замикально-клапанного механізму клубово-сліпокиш-кового переходу відбувається за типом інвагінації, що супроводжується тимчасовим закриттям тонко-товстокишковогосполучення i, як наслідок, розширенням термінального відділу клубової кишки, діаметр якої на 7-му місяці (6,0 0,4 мм) переважає над діаметром проксимального сегмента товстої кишки $(5,7 \pm 0,8$ мм). На становлення дефінітивної будови компонентів клубово-сліпо-кишкового сегмента та варіантів їх будови виявляють синтопічний вплив права нирка, процеси фіксації ободової кишки до задньої черевної стінки та ступінь заповнення кишки меконієм.

Ключові слова: сліпа кишка; клубова кишка; червоподібний відросток; плід; людина.

A number of publications in modern Ukrainian and foreign publications deal with investigations of the anatomy of the ileocecal segment. The data of the majority of authors are fragmentary and incomplete, and mostly deal with investigations of anatomy of a definite form of the ileocecal segment or embryonic formation of iliac papilla. The literature does not contain a common opinion concerning the dynamics of formation of the iliac papilla, variants of its anatomy, mechanism of its sphincter function.

Objective: to determine peculiarities of structure and topographic formation of the ileocecal segment in the perinatal period of human ontogenesis.

Material and methods. The study was conducted on 125 dead fetuses and complexes of organs of fetuses and human newborns without evident macroscopic signs of deviations from the normal structure of the gastro-intestinal tract. To complete our study we have combined complexes of modern and classical morphological and morphological-statistical methods with assessment of reliable obtained results assuming preparation and investigation of series of suc- cessive histological and topographic-anatomical sections, common and thin dissection under the microscope MBS-10 control, morphometry, injection of vessels followed by preparation, contrast radiography.

Results and discussion. After the components of the ileocecal segment are separated, the dynamics of changes of their shape and spatial orientation between themselves can be followed. We agree with the suggestions of certain researchers that in addition to genetically stipulated factors, the character of fixation and plastic processes of growth, meconium filling is one of the factors influencing on the formation and changes of spatial location of the components of the ileocecal segment.

In the result of checking the samples concerning their belonging to one general totality according to Wilcoxon-Mann-Whitney criterion a reliable difference in morphometric parameters of the ileocecal segment components on the significance level at the target significance levels for male and female fetuses was not determined. Therefore, there is no reason to 
assert that morphometric parameters of the ileocecal segment components in fetuses and newborns depend on their sex.

During the fetal period the location of the ileocecal segment components is considerably affected by their interrelations with the right kidney. At the beginning of the fetal period the ileocecal transition is located close to the ventromedial surface of the right kidney upper pole to which dorsolateral surface of the cecum and ileum adjoins. At the sixth-eighth months of development the ileocecal transition shifts in the caudal direction and is located on the ventromedial surface of the middle third and lower pole of the right kidney, and adjoins it by the dorsolateral wall of the cecum and ileum. At the end of the fetal period the ileocecal transition is further shifting to the caudal direction and laterally. The cecum and ileum adjoin the ventrolateral surface of the right kidney lower pole by their dorsomedial surface. In this case the terminal segment of the ileum goes about the right kidney lower pole in the caudal direction. The ventromedial surface of the cecum and ileum adjoins the internal surface of the anterior-lateral abdominal wall. In newborns the ileocecal transition is located at the distance of $8 \mathrm{~mm}$ lower from the right kidney.

A large amount of meconium is accumulated in the lumen of the terminal portion of the ileum till the sixtheighth months of the intrauterine development. Since the ninth month and in newborns the majority of meconium is accumulated in the lumen of the colon.

A number of transformations occur in the histological structure of the ileocecal transition. At the beginning of the fetal period both villi and crypts are found in the mucous membrane of the small and large intestines. In the middle of the fetal period the mucous membrane of the small and large intestines begins to differentiate. Crypts gradually disappear in the structure of the mucous membrane of the small intestine, and at the same time their number increases in the large intestine. At the end of the fetal period and in newborns the villi of the small intestine increase, and the cellular content of their epithelium becomes more variable. The crypts become less deep and wider in the large intestine. The cellular content of the mucous membrane of the small and large intestines is clearly differentiated, and their structure becomes more definite.

During the early period of human ontogenesis the thickness of the walls of the ileocecal transition components increases inharmoniously with the periods of intensive and slow growth. In the period from the sixth to eighth month the thickness of the wall of the ileac terminal portion increases slowly, and in the period from the seventh to ninth month the thickness of the wall of the ileac papilla increases slowly. At the same period the thickness of the large intestine increases quickly. The thickness of the walls of the large intestine grows slower at the ninth and tenth months. At the same period of time the walls of the small intestine increase quickly.

All the above described changes concerning direction, spatial location, morphology and histoarchitectonics occurring with the components of the ileocecal transition are closely connected with themselves, and they occur logically and regularly.

The processes occurring in the ileocecal segment during the fetal period are similar to those occurring during invagination. The lumen of the ileocecal transition at the fourth month of the intrauterine human development is partially closed in the area of the iliac papilla which is evidenced by the shape and character of the iliac opening. At the beginning of the fetal period the iliac papilla is round in shape with a dotted iliac opening. Maximal amount of meconium accumulates in the afferent loop (terminal segment of the ileum) till the $8^{\text {th }}$ month. It results in the formation of the ampule-like dilation of the ileum, decreasing thickness of its wall, flattening and dilation of the crypts and villi of the mucous membrane. During this period the growth of the iliac terminal portion diameter accelerates, that coincides with the period of slow enlargement of the colon diameter. In the middle of the fetal period during formation of the ampule-like dilation of the terminal portion of the ileum the diameter of the latter exceeds the diameter of the colon.

The direction and spatial location of the ileocecal segment components change, which in their turn depends on their relations with the right kidney. At the beginning of the fetal period the ileocecal transition is located close to the medial surface of the right kidney upper pole stipulating dorsolateral direction of the iliac terminal portion. In the middle of the fetal period the ileocecal transition descends to the middle and lower third of the ventromedial surface of the right kidney stipulating ventral direction of the iliac terminal portion.

Further increase of meconium amount results in extension of the "invagination cervix" which is the iliac papilla. At the same time the wall of the iliac papilla becomes thinner, its diameter increases, its shape changes from the round to oval along the axis of the ascending ileum, and the iliac opening changes from dotted to oval. All these changes result in renewal of intestinal permeability beginning from the $8^{\text {th }}$ month. Since this period the large intestine is filled with meconium which is evidenced by enlargement of its diameter prevailing over the diameter of the small intestine, flattening and dilation of the crypts and villi 
of the mucous membrane and thinning of the walls. At the same time appendix shape changes from a curl at the beginning of the fetal period to a loop in the middle. "Invagination head" (iliac papilla) partially suppresses reflux, and due to extension of the wall the colon becomes thinner. At the same time the diameter of the colon intensively increases which coincides in time with the period of slow enlargement of the diameter of the small intestine. The large intestine dilates most intensively in front and lower from the iliac papilla, and the base of the appendix dilates which is the beginning of cecum formation.

Intensive filling of the large intestine with meconium is associated with changes of its location. Relocation of the ascending ileum from the ventromedial surface of the right kidney upper pole to the ventral surface of its middle and lower third causes changes of the location of the ascending ileum from dorsomedial to ventromedial. Decrease of pressure in the terminal portion of the ileum results in enlargement of its wall thickness.

In its turn, extension of the colon walls results in extension of the iliac papilla, which at the beginning is oval in shape perpendicular to the axis of the ascending ileum; the iliac opening becomes a slit, and later at the beginning of an active functioning of the digestive system, cyclic periodical filling of the intes- tine with dejection, it becomes labelloid in shape. The appendix becomes a hook in shape.

Conclusions. Macroanatomical signs of the cecum are clearly determined in the neonatal period which is evidenced by dilation of the initial segment of the large intestine proximally from the iliac papilla and formation of anatomical border between the colon and appendix.

Morphogenesis of the iliac papilla is characterized by five successive shape-generating stages: 1) round papilla with a dotted opening - at the $4-5^{\text {th }}$ months; 2 ) oval papilla located longitudinally - at the $6-7^{\text {th }}$ months; 3 ) round papilla with a gaping opening - at the $8-9^{\text {th }}$ months; 4) oval papilla located transversally - on the $10^{\text {th }}$ month; 5) labelloid (bilabial) papilla - in the neonatal period.

Delay of the formation processes of the iliac papilla structure results in the formation of its anatomical variants - round papilla with stellate opening or oval papilla with slit-like opening. In case iliac papilla is lacking the ileocecal segment becomes of a funnel shape that is anatomical base of possible occurrence of reflux-ileitis.

Prospects of further studies. Investigation of anatomical peculiarities of the ileocecal segment components during postnatal period is considered to be reasonable.

\section{Список використаної літератури}

1. Mukohyama J, Sumi Y, Kanemitsu K, Hasegawa H, Yamamoto M, Kanaji S, Matsuda Y, et al. Laparoscopic ileocecal resection can be applied for appendiceal cancer with an ileal fistula: A case report. Int J Surg Case Rep. 2018 Oct 8;52:120-4. doi: 10.1016/j.ijscr.2018.10.004.

2. Ekici U, Yilmaz S, Tatli F. Ileocecal invagination due to an inflammatory fibroid polyp. A case report. Ann Ital Chir. 2018;89:347-9.

3. Bhutra S, Singh A, Devpura TP. Emergency Ileo-cecal Anastomosis with Inclusion of Appendicular Stump in Terminal Ileal Pathology: A Newer Approach. Niger J Surg. 2018 Jul-Dec;24(2):116-120. doi: 10.4103/njs.NJS_35_17.

4. Binkovitz LA, Kolbe AB, Orth RC, Mahood NF, Thapa P, Hull NC, Thacker PG, Moir C. Pediatric ileocolic intussusception: new observations and unexpected implications. Pediatr Radiol. 2018 Sep 19. doi: 10.1007/s00247-018-4259-9.

5. Kimura S, Iida H, Gunji N, Gohongi T, Ogata T. Stool filling of an intestinal duplication cyst at the ileocecal valve triggers colonic intussusception: a case report. Surg Case Rep. 2018 Sep 15;4(1):116. doi: $10.1186 / s 40792-018-0527-z$.

\section{References}

1. Mukohyama J, Sumi Y, Kanemitsu K, Hasegawa H, Yamamoto M, Kanaji S, Matsuda Y, et al. Laparoscopic ileocecal resection can be applied for appendiceal cancer with an ileal fistula: A case report. Int J Surg Case Rep. 2018 Oct 8;52:120-4. doi: 10.1016/j.ijscr.2018.10.004.

2. Ekici U, Yilmaz $S$, Tatli F. Ileocecal invagination due to an inflammatory fibroid polyp. A case report. Ann Ital Chir. 2018;89:347-9.

3. Bhutra S, Singh A, Devpura TP. Emergency Ileo-cecal Anastomosis with Inclusion of Appendicular Stump in Terminal Ileal Pathology: A Newer Approach. Niger J Surg. 2018 Jul-Dec;24(2):116-120. doi: 10.4103/njs.NJS_35_17.

4. Binkovitz LA, Kolbe AB, Orth RC, Mahood NF, Thapa P, Hull NC, et al. Pediatric ileocolic intussusception: 
new observations and unexpected implications. Pediatr Radiol. 2018 Sep 19. doi: 10.1007/s00247-018-4259-9. 5. Kimura S, Iida H, Gunji N, Gohongi T, Ogata T. Stool filling of an intestinal duplication cyst at the ileocecal valve triggers colonic intussusception: a case report. Surg Case Rep. 2018 Sep 15;4(1):116. doi: 10.1186/s40792-018-0527-z.

\section{ФЕТАЛЬНАЯ АНАТОМИЯ ПОДВЗДОШНО-СЛЕПОКИШЕЧНОГО СЕГМЕНТА}

Резюме. Исследованию анатомии подвздошно-слепокишечного сегмента посвящено большое количество публикаций на страницах современных и зарубежных научных изданий. Данные большинства авторов фрагментарные и неполные, в большинстве своем посвящены или исследованию анатомии дефинитивной формы подвздошно-слепокишечного сегмента или эмбрионального формообразования подвздошного сосочка. В литературе отсутствует общая точка зрения о динамике становления подвздошно-слепокишечного сосочка, вариантов его анатомии, механизму его запирательной функции. Исследования проведены на 125 трупах и оргадокомплексах плодов и новорожденных человека без явных макроскопических признаков нарушения нормального строения желудочно-кишечного тракта. Морфогенез запирательно-клапанного механизма подвздошно-слепокишечного перехода происходит по типу инвагинации, что сопровождается временным закрытием толнко-толстокишечного соединения и, как следствие - разширением терминального отдела подвздошной кишки, диаметр которой на 7-м месяце $(6,0 \pm 0,4$ мм) превалирует над диаметром проксимального сегмента толстой кишки $(5,7 \pm 0,8$ мм). На становление дефінитивного строениякомпонентов подвздошно-слепокишечного сегмента и вариантов их строения производят синтопическое влияние: правая почка, процессы фиксации подвздошной кишки к задней стенке живота и степень наполнения кишки меконием.

Ключевые слова: слепая кишка; подвздошная кишка; червеобразный отросток; плод; человек.

\section{FETAL ANATOMY OF THE ILEOCECAL SEGMENT}

Abstract. A number of publications in modern Ukrainian and foreign publications deal with investiga-tions of the anatomy of the ileocecal segment. The data of the majority of authors are fragmentary and incomplete, and mostly deal with investigations of anatomy of a definite form of the ileocecal segment or embryonic formation of iliac papilla. The literature does not contain a common opinion concerning the dynamics of formation of the iliac papilla, variants of its anatomy, mechanism of its sphincter function. The study is conducted on 125 dead fetuses and complexes of organs of fetuses and human newborns without evident macroscopic signs of deviation from a normal structure of the digestive tract. Morphogenesis of the sphincter-valve mechanism of the ileocecal transition is of invagination type accompanied by temporary closing of the junction between the small and large intestines, and as a result, dilation of the terminal portion of the ileum, diameter of which on the 7th month of develop-ment $(6,0 \pm 0,4 \mathrm{~mm})$ prevails over the diameter of the proximal segment of the colon $(5,7 \pm 0,8 \mathrm{~mm})$. Formation of a definite structure of the components of the ileocecal segment and variants of its struc-ture is affected by a syntopogenous influence of the right kidney, the processes of colon fixation to the posterior abdominal wall, and degree of filling the intestine with meconium.

Key words: caecum; ileum; appendix; fetus; human.

Відомості про автора:

Проняєв Дмитро Володимирович - к. мед. н., доцент кафедри анатомії, топографічної анатомії та оперативної хірургії ВДНЗ України “Буковинський державний медичний університет”, м. Чернівці;

Бірюк Ігор Григорович - к.мед.н., доцент., зав. кафедри медицини катастроф та військової медицини ВДНЗ України “Буковинський державний медичний університет”, м. Чернівці;

Козарійчук Наталія Ярославівна - асистент кафедри офтальмології ім. Б.Л. Радзіховського ВДНЗ України “Буковинський державний медичний університет”, м. Чернівці;

Галагдіна Алла Авелівна - к.мед.н., доцент., кафедри хірургічної стоматології та щелепно-лицевої хірургії, ВДНЗ України “Буковинський державний медичний університет”, м. Чернівці.

Гончаренко Валентина Анатоліївна - асистент кафедри стоматології дитячого віку ВДНЗ України “Буковинський державний медичний університет”, м. Чернівці.

Information about author:

Proniaiev Dmytro Volodymyrovych - Candidate of Medical Sciences, Assistant Professor, of the Department of topographical anatomy and operative surgery of the HSEE of Ukraine "Bukovinian State Medical University", Chernivtsi City. 
Biryuk Igor Hryhorovych - Candidate of Medical Sciences, Assistant Professor, chief of the Department, of the Disasters Medicine and Military Medicine of the HSEE of Ukraine "Bukovinian State Medical University", Chernivtsi City.

Kozariichuk Nataliya Yaroslavivna - asistent of the B.L. Radzikhovckyi Department of Ophthalmology of the HSEE of Ukraine "Bukovinian State Medical University", Chernivtsi City.

Halahdina Alla Avelivna - Candidate of Medical Sciences, Assistant Professor of the Department of Surgical Stomatology and Maxillofacial Surgery of the HSEE of Ukraine "Bukovinian State Medical University", Chernivtsi City.

Goncharenko Valentyna Anatoliivna - asistent of the Department of pediatric dentistry of the HSEE of Ukraine "Bukovinian State Medical University", Chernivtsi City. 